\title{
Informational ergonomics and design: signage design for Monte Sião Camp
}

\author{
Marques, Luiz Guilherme Oliveira ${ }^{\mathrm{a},}$, Cardoso, Vânia Maria Batalha ${ }^{\mathrm{b}}$ \\ ${ }^{a}$ Graphic and Product Designer, Federal University of Amazon, Av. Ephigênio Sales, 2226, Quadra B, Casa 11, \\ Manaus, AM, Brasil. \\ ${ }^{\mathrm{b}}$ Design and Graphic Expression Department, Federal University of Amazon, Av. General Rodrigo Octávio \\ Jordão Ramos, 3000, Campus Universitário, Coroado I-Manaus, AM, Brasil.
}

\begin{abstract}
This paper refers to the development of a signage system, driven by the vector of Signage Design and Informational Ergonomics associated with Regulatory Standards. The methodology of the Ergonomic Intervention of Moraes and Mont'Alvão (2003), in its early stages, and the Method of the Signage Pyramid of Calori (2007) were used to develop the research, data collection and analysis and to guide the design by a signaling system. The system contemplated by this job is called Mount Zion, a site of 19 hectares, which has signs of disturbance. As a result, we obtained a signaling system, with graphic features that refer to formal-site, capable of meeting the needs of orientation and displacement inherent to the site.
\end{abstract}

Keywords: signage design, informational ergonomics, standards, camp

\section{Introduction}

In unknown locations, it is common the need for guidance concerning localization and displacement of people. The signage is intended to meet this need, providing information regarding the referred site and also about the directions and destinations to which you plan to arrive.

In signaling projects, the contributions of Design and Ergonomics Informational are essential, since the design reinforces shape and visual features of a particular system, and once incorporated into the Informational Ergonomics, these meet the specific needs of functionalities regarding the environment and situation, focusing on the human subject and its activities. Such requirements would not benefit from the implementation of a business and general signage, produced industrially.

The system to be included in this study is the Mount Zion a 19 hectares wide site, used for church camps and retreats, whose signage is almost nonexistent. During the development of camping activities on the site, particularly in the early days of camp, one can observe campers rather confused as to where buildings are and how should move within the site. Thus, it becomes necessary to put together a signage that fulfills the needs of its users and which facilitates the communication of understandable and enlightening information. Research, method and the development a project specific cue to Mount Zion are then presented, considering the needs inherent to it, meeting the requirements listed in accordance with regulatory standards.

The term signal is usually associated with traffic, describing plaques, paintings, lights and elements that organize and regulate vehicular pedestrian and traffic, among others. However, Costa (cited in Pereira and Vieira, 2009), on a study of group movements of groups of individuals from different cultures and geographic origins in different situations, gives rise to fear señalética, equivalent to "signage" in English. According to the author, the term can be considered a signal evolution applied to particular problems of

\footnotetext{
* Corresponding author e-mail: lgmgold@hotmail.com
} 
spatial information, whose language is totally focused on the individual and predominantly synthesized and functional - maximum information with minimum effort and elements from the receiver to its immediate and unequivocal understanding and identification.

Calori (2007) speaks of Environmental Graphic Design (EGD), definition. The author advocates that the contemporary activity of EGD involves the development of a systematic plot, cohesiveinformational and visually unified for a given place within the built environment. Such places can range from a single building to a complex of buildings or a city or a transportation network connecting multiple locations regionally or nationally - all with complex communication needs. (P.4 da Calori)

Old (2007) in discussing the origin and adoption of the term "signage design," reports the essential link between the design by this communication system and principles of Informational Ergonomics, since the aim of "signage" is to optimize and sometimes, enabling patterns of displacement in human built environments, and these elementary or complex communication needs.

Principles of Ergonomics Informational addressed, we can mention the human perceptual and cognitive systems; anthropometry; visibility, readability, memory, psychological and symbolic colors, symbols of universal understanding, reading and understanding verbal instructions, decision-making hierarchy visual task, the character size and speed of display, Gestalt, and types of signaling elements, according to its purpose, content and method of installation.

During the research of the Brazilian Standards and Manuals Transit Brazilians and foreigners, it was noticed that as soon as the data for "sinage" and EGD, these Rules and Manuals contains an essential link with the principles of Informational Ergonomics, regulating and recommending its use . Were extracted and applied recommendations of ISO 9050:2004 - Accessibility to buildings, furniture, spaces and urban equipment, the NR 12 - Machinery and equipment, the NR 26 - Safety signs, of ISO 1343-2/2004 - Safety signs against fire and panic, the Brazilian Traffic Code (2008), Road Signs Manual (1998), Road Signs Manual (2006) and Vertical Manual Signaling (Roque, 2005).

\section{Objectives}

\subsection{General Objective}

To develop a signage system to Monte Sião camp in accordance to the specificities of place and according to signaling standards.

\subsection{Specific Objectives}

- To identify roads, boundaries, directions to different areas and the location of each facility and further information, considering the organization of the camp, covering different areas, buildings and their spaces;

- To propose signs in accordance with individual differences and restrictions on users;

- To apply concepts of Signage Design and Informational Ergonomics;

- Observe requirements and standards requirements for signaling.

\section{Justification}

The Monte Sião camp is extensive territory and has long distances between its facilities, without proper signage fulfilling its needs related to displacement, location and security. The implementation of signage at this location can meet these needs, and help its users stay safe and understand the organization of the camp during their stay on site, contributing to the sense of welcoming transmitted by institution to the camper.

Furthermore, considering the number of people circulating in retreats and visiting the camp and the current inefficient signaling of Monte Sião, it becomes evident the importance of developing and implementing an effective and specific signage system, considering the site's characteristics, facilitating the movement, identifying sites and providing security for its users in the camp.

\section{Monte Sião}

Monte Sião (figure 1) is a 19 acre site, located on the AM-010 state highway, $180 \mathrm{~km}$ from Manaus, in Amazonas State, Brazil. It belongs to the Presbyterian Church of Manaus and it is used for retreats and camps. It has living quarters, recreation and fellowship areas and it is visited by different age and various social-economic groups. Its current signaling is inefficient and does not contemplate the identifica 


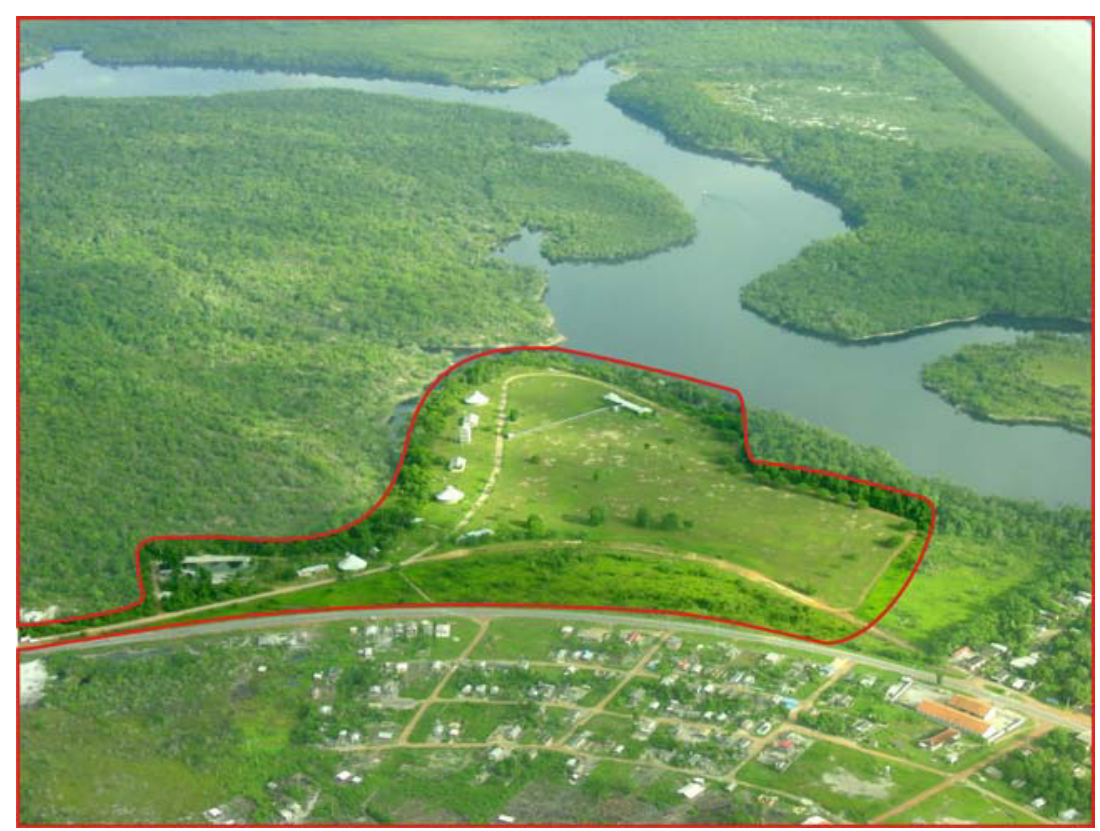

Fig. 1 - Monte Sião - top view

tion of facilities and spaces, the movement of users, the hazard warnings and restrictions. It is made by a painting of the site's name in the entrance portal, numbering of the rooms of the dorms and tower, four road regulation signs, and two improvised signs and painting identifying gender in two out of three bathrooms.

\section{Methodology}

For data collection, it was used the initial stages the Ergonomic Intervention of Moraes and Mont'Alvão (2003), which guided the analysis, structured records and embraces the mapping of difficulties observed the development of activities on the Monte Sião camp. Photographic records and system models were used to systematize the system, to show their systemic disorders, defining, prioritizing and consolidating necessities in order to reach recommendations and requirements. Iida (2005) was used in the production of focused questionnaires and interviews, as well as informational ergonomics parameters and guidelines for the development of information system.

The method of Pyramid Signaling Calori (2007), which consists of project development from three interrelated components: the system information content, the graphics system and the system of physical devices, in this sequence. The system information content deals with the development of the information itself, as well as a location in the same environment. The graphics system deals with the development of two-dimensional material - typography, symbols, arrows, etc.. The system of physical devices is the three-dimensional system board, and support, fixing, connection of subsystems, material and workmanship. Using this method culminates with the development projectual signaling system.

\section{Data collection}

During the assessment phase and Mont'Alvão Ergonomizadora de Moraes (2003) was made initially, the systematization of the system man-machine task, from the models and serial position called Characterization and Modeling System Communicational System. These models aim to elucidate the function, objectives, procedures and steps of the system, the process of reporting.

After the systematization, we followed it step for Curriculum, which relate to the needs of the system. We used the taxonomic classification and categorization of the ergonomic problems of the system manmachine task proposed by Moraes and Mont'Alvão (2003), according to which information needs were identified / visual, cognitive shift, spatial / architectural interiors, natural and accident. Were also related to systemic dysfunction from unwarranted observa- 
tion results of the system, incidents and downtime, poor performance of the system and compromising the quality of the system.

Questionnaires were applied with open, closed, open and closed and unstructured interviews. As suggested by Iida (2005), was developed and implemented a pilot questionnaire with a smaller group of users, and after this assessment was a questionnaire prepared and able to meet the needs of the research. Through the responses of 147 users, it was possible to verify the user's needs, from your point of view.

An analysis of similar signaling systems present and working in situations similar to situations in which this project deals in order to explore and clarify the different possibilities of application of signaling elements, considering how, installation, lighting, technology used and characteristics of information.

As directed by the method of the Pyramid Signaling Calori (2007), it was a grab-bag of all destinations and paths, arranging them according to a study by flow offsets, summarizing the system of information content. Concomitant with the development stage of about design alternatives, we studied typography, symbols, colors and shapes and legibility of these, combined with the distance and speed of display on the site, allowing the system size chart. According to the system of information content and the graphics system, we studied dimensions, materials and forms of support of signaling elements, composing the three-dimensional system.

From the collection and analysis of data and issues discussed in the theoretical framework, characterized that must meet the requirements and design parameters that guide it, categorizing requirements and usage parameters, formal, function and technicalproductive. These guided the step of generating about design alternatives, which are listed, developed and presented possible solutions to the needs in question.

\section{Result}

We therefore generated three alternatives with different concepts:

1 - dominant elements in place - from architectural and natural shapes and colors present on the site has generated a standard graph-formal visually refers to the camp. (Figure 2)

2 - Sunny Hill - has generated a pattern of signaling elements from the meaning of the name Zion (Zion in English), which in its Hebrew origin, Zion means "sunny place," according to the Electronic Journal Bible Bytes Online.

3 - Architectural Elements - based on the formal characteristic of the structure of wood rafter roofs of buildings and roofs in their own, a structure was generated for the graphics system and information.

As an alternative selection tool, we used the evaluation matrix, using criteria based on the requirements and parameters about design and legibility, reinforcing the image of local correlations between subsystems, include the visually impaired, viewing distance, weather resistance, differential form, materials, production and assembly affordable, late night viewing and maintenance. In this matrix, we selected the third alternative.

Then came the development of alternative be selected according to the needs met through the site, collecting and analyzing data, and in accordance with guidelines of Informational Ergonomics and Standards. To this end, we resorted to study the typography, color, formal, diagramming and visual pattern. Tests were conducted and used to validate simulations. As a result, we obtained thirteen types of signaling elements (Figures 2 to 5):

- port-numbered plates Room (A);

- ID cards door to internal toilets (B and C) and external (D), according to the same sex and specificity;

- nameplates areas (E, F and G);

- nameplate and targeting areas $(\mathrm{H})$;

- boards of direction (I);

- schematic map;

- mini totems with map and identification of buildings ( $\mathrm{J})$;

- targeting totems for pedestrians and vehicles $(\mathrm{K})$, close to the internal road;

- totems on the highway (L), indicating approach to the site, and

- adaptation to the entrance porch (M).

In addition to the evidence presented, have been proposed elements of traffic signs and safety and signaling elements accessible to the visually impaired, in accordance with the Rules and Manuals consulted. Finally, we made a detailed and technical details of production costs of signaling.

Final Thoughts

The project developed about design met the requirements listed in the requirements phase and parameters as well as authors of the guidelines and standards included in the theoretical framework. 


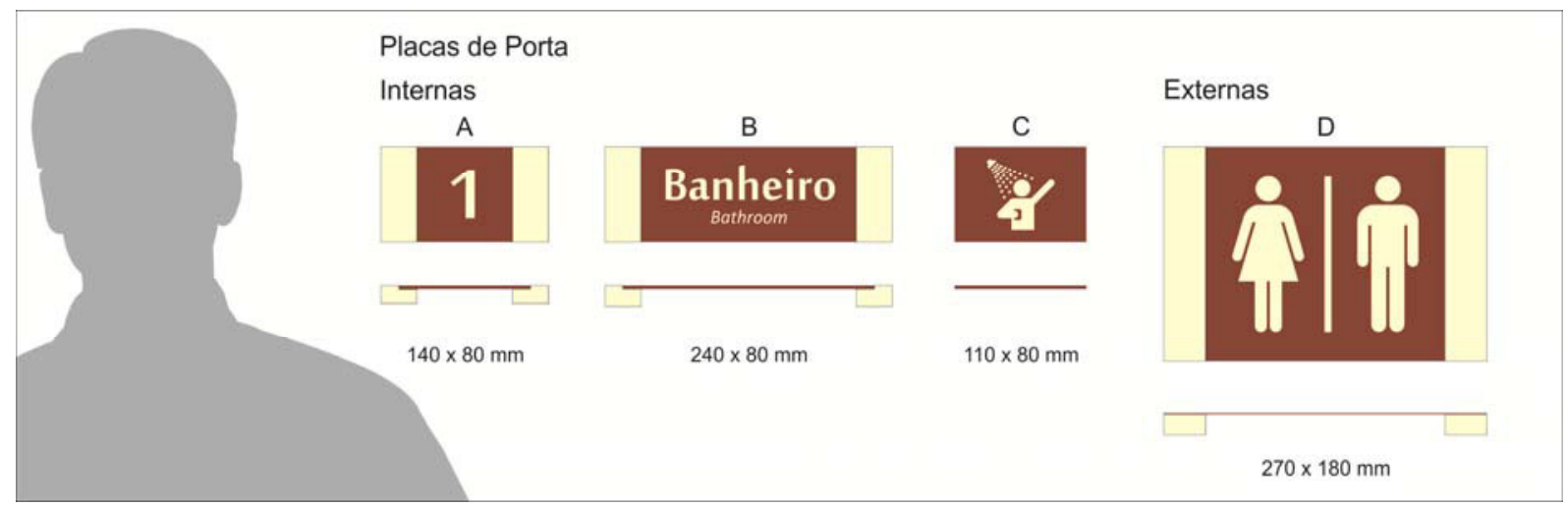

Fig. 2 - Signs from A to D

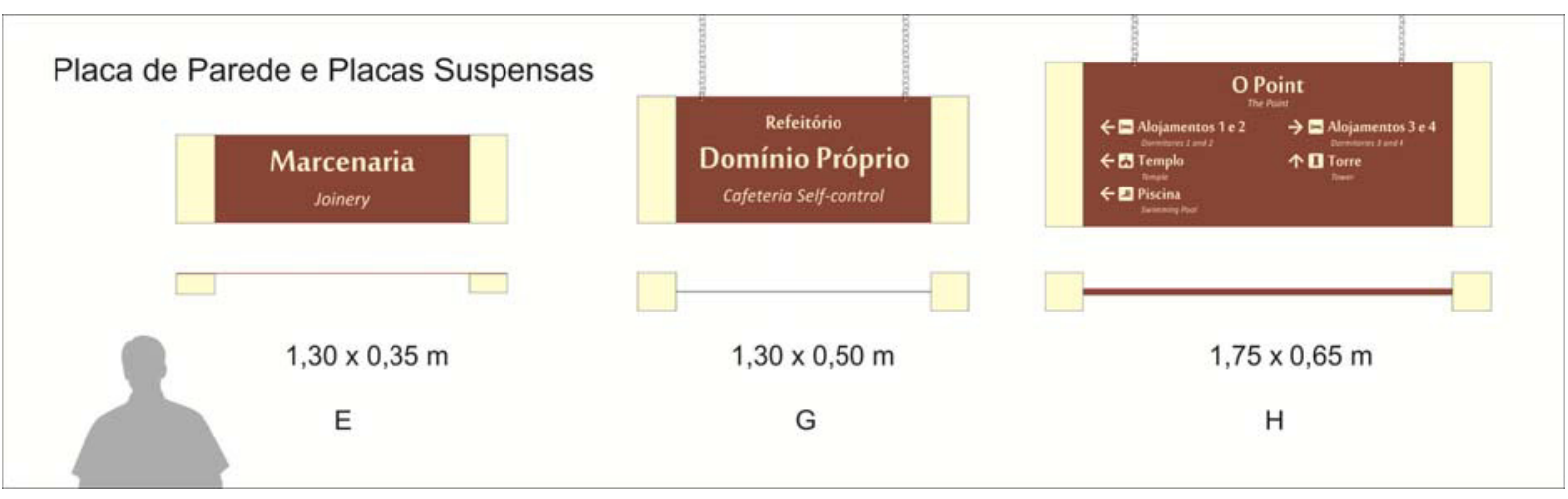

Fig. 3 - Signs from $E$ to $H$

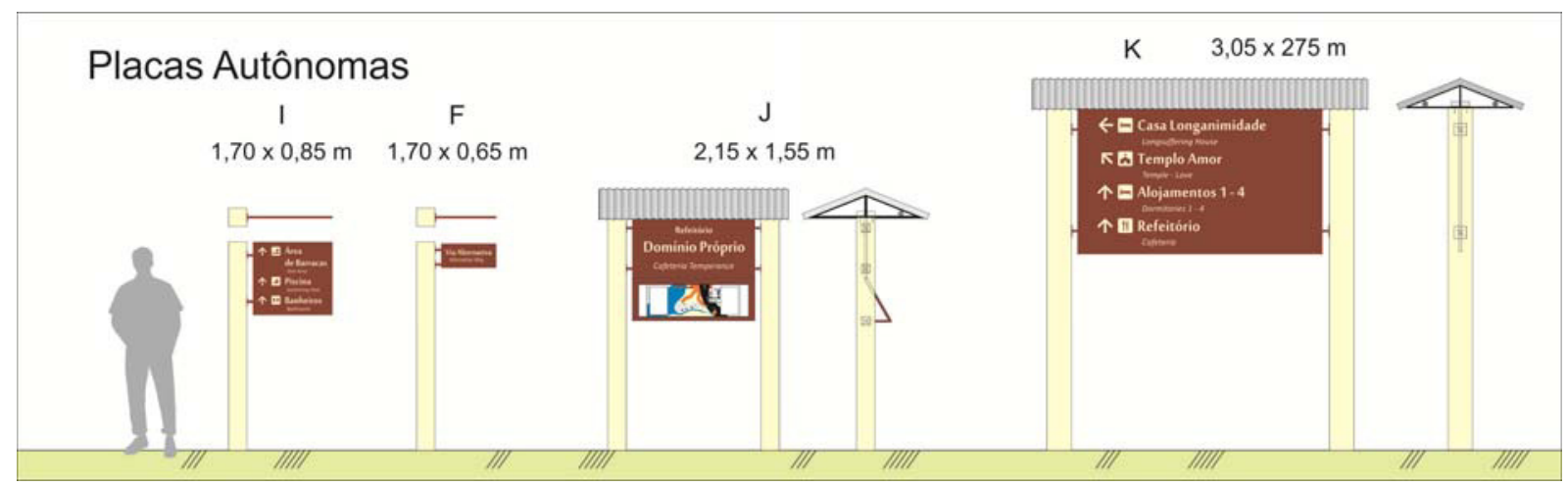

Fig. 4 - Signs from I to K 


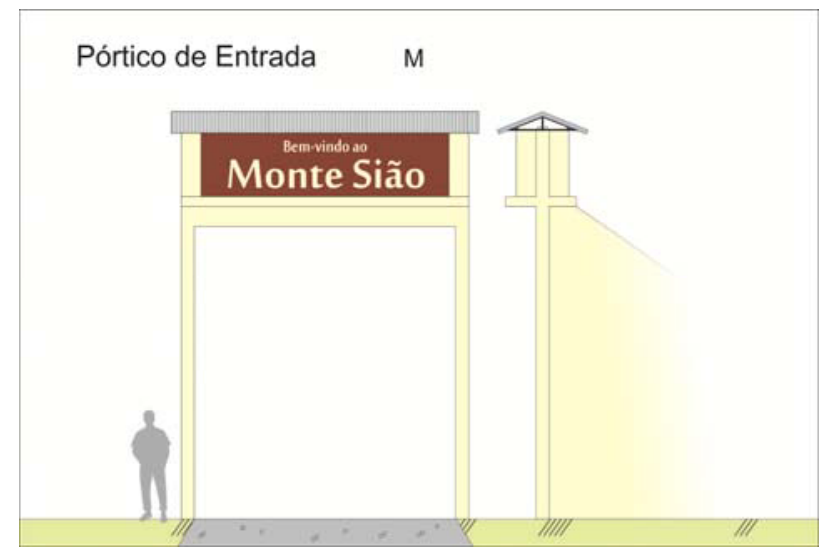

Fig. 5 - Sign M

It included identification signage, direct and targeted domestic and foreign, which, once implemented, will give the organization to Mount Zion and security to its users, and to establish itself as a guideline for formal models and graphics to be used in other systems in place.

It was possible to assimilate, through inquiry, the opinion of users of the system and their suggestions for improvements, both in relation to movements and use of signs, and in relation to the conditions of accessibility and maintenance of the site. As a consequence, it was suggested the display and implementation of accessibility and mobility to wheelchair users, elderly and obese.

The study represents a source of research Signaling Design, Ergonomics and Informational Standards Manuals and related signaling and also on Mount Zion and the profile of its users.

\section{References}

[1] ABNT. NBR 13434-2. Sinalização de segurança contra incêndio e pânico. Parte 2: Símbolos e suas formas, dimensões Rio de Janeiro: ABNT, 2004.

[2] ABNT. NBR 9050:2004. Acessibilidade a edificações, mobiliário, espaços e equipamentos urbanos. Rio de Janeiro: ABNT, 2004.

[3] BRASIL. Código de Trânsito Brasileiro. $3^{\mathrm{a}}$ Ed. Brasília: DENATRAN, 2008.

[4] BRASIL. Governo do Estado de São Paulo. Secretaria dos Transportes. Departamento de Estradas de Rodagem. Manual de sinalização rodoviária. V. 3 Obras, serviços de conservação e emergência. $2^{a}$ ed. São Paulo: Departamento de Estradas de Rodagem do Estado de São Paulo, 2006.

[5] BRASIL. Ministério dos Transportes. Departamento Nacional de Estradas de Rodagem. Diretoria de Desenvolvimento Tecnológico. Divisão de Capacitação
Tecnológica. Manual de sinalização rodoviária. $2^{\mathrm{a}}$ Ed. Rio de Janeiro: IPR, 1998.

[6] Calori, Chris. Signage and Wayfinding Design: a complete guide to creating environmental graphic design systems. New York: Wiley John \& Sons, 2007.

[7] Iida, Itiro. Ergonomia: Projeto e Produção. 2 ${ }^{\mathrm{a}}$ ed. São Paulo: Edgard Blucher, 2005.

[8] Oliveira, Rodrigo Gomes de. Norma Regulamentadora NR 12 - Máquinas e Equipamentos. Disponível em $<$ engenheirorodrigo.wordpress.com/2009/02/08/normareguladora-nr-12-maquinas-e-equipamentos/> Acesso em: 24 de junho de 2010.

[9] Pereira, Clauciane Vivian; VIEIRA, Milton Luiz Horn. Design gráfico ambiental para a sustentabilidade. In: $2^{\circ}$ Simpósio Brasileiro de Design Sustentável, 2009. Anais. São Paulo, 2009.

[10] Roque, Carlos de Almeida. Sinalização Vertical. Lisboa, 2005.

[11] SIONISMO. A Bíblia em Bytes Online. Disponível em $<$ www2.uol.com.br/biblia/ revista/edicao3/sionis.htm> Acesso em 2 de outubro de 2010.

[12] Velho, Ana Lucia de Oliveira Leite. O design de sinalização no Brasil: a introdução de novos conceitos de 1970 a 2000. Rio de Janeiro: PUC-RIO, 2007. Tese de Mestrado. 